\title{
Effect of the inclusion of fish residue oils in diets on the fatty acid profile of muscles of males and females lambari (Astyanax altiparanae) ${ }^{1}$
}

\author{
Ligia Uribe Gonçalves², Felipe Ferroli ${ }^{2}$, Elisabete Maria Macedo Viegas ${ }^{2}$
}

\author{
${ }^{1}$ Financially supported by FAPESP and CNPq. \\ ${ }^{2}$ Universidade de São Paulo, Faculdade de Zootecnia e Engenharia de Alimentos, Departamento de Zootecnia, Av. Duque de Caxias Norte, 225, \\ CEP 13635-900, Pirassununga, SP, Brazil.
}

\begin{abstract}
This study evaluated the effects of two lipids sources of fish residue (tilapia and salmon) compared with a vegetable oil source (soybean oil) on the fatty acid profiles of male and female lambari. This experiment was developed in a completely randomized experimental design in a $3 \times 2$ factorial arrangement, totaling 6 treatments resulting from the combination of the three experimental diets for both sexes, with four replications for each treatment. This study involved 120 male $(2.58 \pm 0.13 \mathrm{~g})$ and 72 female lambari $(4.00 \pm 0.09 \mathrm{~g})$, fed the experimental diets twice a day until apparent satiation for a period of 60 days. Oleic, linoleic, palmitic and stearic fatty acids were found at higher concentrations in all experimental oils and diets, as well in the muscle of male and female lambari. The low amounts of arachidonic, eicosapentaenoic and docosahexaenoic acids in the experimental diets and subsequent greater concentrations in muscle tissue, suggested that lambari are able to desaturate and elongate the chain of fatty acids with 18 carbons. The fish of both sexes that received the diet with soybean oil showed high levels of n-6 fatty acids, especially of C18: 2n-6 and low levels of eicosapentaenoic and docosahexaenoic acids. The diet with salmon residue oil promoted higher levels of fatty acids of the n- 3 series and resulted in the best $n-3 / n-6$ ratio in the muscle of male and female lambari. The oils from fish residues can be a substitute for traditional fish oil and its use in the lambari diets does not impair its growth.
\end{abstract}

Key Words: docosahexaenoic acid, eicosapentaenoic acid, salmon residue oil, soybean oil, tilapia residue oil

\section{Introduction}

Although fishmeal and fish oil provide sufficient quantities of amino acids and essential fatty acids, the use of these ingredients in the fish nutrition does not guarantee the sustainability of aquaculture (Tacon \& Metian, 2008), since the production in the fishery sector is stagnant (FAO, 2010).

Foods rich in fatty acids from the n-3 series, like eicosapentaenoic (EPA, C20: 5n-3) and docosahexaenoic acids (DHA, C22: 6n-3), and with a balanced n-3/n-6 ratio are related to several human nutritional benefits (Bazan, 2006; Mozaffarian et al., 2005). Therefore, a major disadvantage in replacing fish oil by vegetable oils in the preparation of fish feed is the inevitable change in the fatty acid profile composition of fish muscle. Preparations containing a large amount of vegetable-based ingredients will promote increased levels of $n-6$ and decreased levels of $\mathrm{n}-3$, resulting in the loss of that particular nutritional health benefit (Turchini et al., 2009).

A strategy to improve the fatty acid profile composition in the fish muscle, while also promoting environmental sustainability, is the use of oil obtained from fish-processing residues (Turchini et al., 2009). Studies have shown the efficiency of trout offal oil (Turchini et al., 2003), catfish residue oil (O’Neal \& Hohler, 2008) and tilapia residue oil (Boscolo et al., 2008).

The lambari-do-rabo-amarelo species belongs to the family Characidade and subfamily Tetragonopterinae, previously classified as Astyanax bimaculatus, receiving the new nomenclature Astyanax altiparanae (Garutti \& Britski, 2000). This species has become an attractive option for commercial production, because of the easy capture of fingerlings, their rapid growth, their simplicity and ease in handling, as well as their great potential for the commercial market (Porto-Foresti et al., 2005). Due to these characteristics, the lambari has been investigated concerning factors related to its production, such as stocking density (Vilela \& Hayashi, 2001), feeding level and frequency (Hayashi et al., 2004; Meurer et al., 2005) and nutrition (Abimorad \& Castellani, 2011; Cotan et al., 2006; Signor et al., 2008).

With the growth of aquaculture, it has become necessary to carry out research studies on the use of generated residues in a species with a potential for farming. The objective of this study was to investigate the effects of two sources of 
oil obtained from tilapia and salmon residues, compared with soybean oil, upon the fatty acid profile compositions found in lambari.

\section{Material and Methods}

The experiment was conducted in Pirassununga $\left(21^{\circ} 59^{\prime} \mathrm{S}, 47^{\circ} 26^{\prime} \mathrm{W}\right)$, São Paulo state, Brazil, within a closed system with constant water circulation and oxygenation; a photoperiod of 12 hours of light and 12 hours of darkness. Water quality parameters, $\mathrm{pH}$, dissolved oxygen and temperature were all monitored on a daily basis and the concentrations of ammonia and nitrite were monitored weekly.

Mean temperature, dissolved oxygen, $\mathrm{pH}$, ammonia and nitrite levels observed during the experimental period were $25.92 \pm 0.4{ }^{\circ} \mathrm{C} ; 4.60 \pm 0.2 \mathrm{mg} / \mathrm{L} ; 7.37 \pm 0.15 ; 0 \mathrm{ppm}$ and $0 \mathrm{mg} / \mathrm{L}$, respectively. These values were within the acceptable levels for the farming of Astyanax altiparanae (Porto-Foresti et al., 2005).

Three experimental diets were formulated (Table 1) with the same lipid content $(50 \mathrm{~g} / \mathrm{kg})$; their only variation was the source of oil: soybean and tilapia and salmon residue. The control diet was formulated with soybean oil purchased in Pirassununga, São Paulo, Brazil. The tilapia residue oil was extracted by means of centrifugation of the carcass without any milled viscera and head for 30 minutes (Centrifuge Thermo IEC Centra GP8R, $4200 \mathrm{rpm}$ ). The lipid supernatant fraction from the Nile tilapia residue was collected with a pipette and filtered using a vacuum pump, containing filter paper (Whatman \#4) and sodium sulfate for retaining the solid waste and remaining moisture. The salmon residue oil was provided by Damm Food Products Ltd (São Paulo, SP), extracted under heat during the preparation of fish meal. The combination of fish meal, soybean meal and corn gluten was used as protein source (Table 2). Corn and wheat bran were used as sources of carbohydrates. In order to minimize lipid oxidation, an antioxidant (BHT) was added to the fish feed formulation, which was extruded into grains of $2 \mathrm{~mm}$ of diameter.

This experiment was developed in a completely randomized design, in a $3 \times 2$ factorial arrangement, totaling 6 treatments resulting from the combination of the three experimental diets for both sexes, with four replications (tank) for each treatment. This study involved 192 lambari during the growth period; their sex was already identifiable (spines on the anal fin of the male). This total comprised 120 males (average weight $2.58 \pm 0.13 \mathrm{~g}$ ) and 72 females (average weight $4.00 \pm 0.09 \mathrm{~g}$ ). Each experimental group was stocked in fiberglass tanks $(60 \mathrm{~cm} \times 55 \mathrm{~cm} \times 50 \mathrm{~cm})$ having a useful capacity of $120 \mathrm{~L}$. The fish were fed the extruded experimental diets twice a day (8:00 am and 5:00 pm) until apparent satiety, for a period of 60 days. The cleaning of each tank was done on alternate days.

At the end of the experiment, three fish per replicate were sacrificed with an overdose of anesthetic (benzocaine, $\mathrm{g} / \mathrm{L})$; these fish were then frozen $\left(-80^{\circ} \mathrm{C}\right)$ for evaluation of the fatty acid profile.

Samples of the experimental diets and the fish carcasses were obtained for determination of the proximate composition (moisture, crude protein, ash and lipids), using methodology from the AOAC (2005), and only the muscle tissue was used for the determination of the fatty acid profiles from each treatment.

The method used for the total lipid extraction was the one described by Bligh \& Dyer (1959). The lipids were saponified according to the procedures described by Hartman \& Lago (1973). The methyl esters from the fatty acids were separated using gas chromatography and the identification of fatty acids was performed by comparing the retention times of fatty acid standards (Sigma no. Cat 189-19). To determine the fatty acids profile, a gas

Table 1 - Formulation and proximate composition of experimental diets

\begin{tabular}{|c|c|c|c|}
\hline \multirow[b]{2}{*}{ Ingredients $(\mathrm{g} / \mathrm{kg})^{1}$} & \multicolumn{3}{|c|}{ Experimental diets } \\
\hline & Soybean oil & $\begin{array}{c}\text { Tilapia } \\
\text { residue oil }\end{array}$ & $\begin{array}{l}\text { Salmon } \\
\text { residue oil }\end{array}$ \\
\hline Soybean meal & 290.8 & 290.8 & 290.8 \\
\hline Corn (grain) & 260.0 & 260.0 & 260.0 \\
\hline Wheat bran & 107.0 & 107.0 & 107.0 \\
\hline Corn gluten & 85.0 & 85.0 & 85.0 \\
\hline Corn starch & 30.0 & 30.0 & 30.0 \\
\hline Fishmeal & 120.0 & 120.0 & 120.0 \\
\hline Kaolin & 50.0 & 50.0 & 50.0 \\
\hline Soybean oil & 50.0 & - & - \\
\hline Tilapia residue oil & - & 50.0 & - \\
\hline Salmon residue oil & - & - & 50.0 \\
\hline Vitamin and mineral supplement ${ }^{2}$ & 5.0 & 5.0 & 5.0 \\
\hline Salt & 2.0 & 2.0 & 2.0 \\
\hline Butylated hydroxytoluene & 0.2 & 0.2 & 0.2 \\
\hline \multicolumn{4}{|l|}{ Analysis } \\
\hline Dry matter $(\mathrm{g} / \mathrm{kg})$ & 923.7 & 931.3 & 936.1 \\
\hline Crude protein $(\mathrm{g} / \mathrm{kg})$ & 325.5 & 315.3 & 320.2 \\
\hline Crude lipid (g/kg) & 65.3 & 79.6 & 72.7 \\
\hline Crude fiber $(\mathrm{g} / \mathrm{kg})$ & 33.5 & 33.5 & 33.5 \\
\hline Ash $(g / k g)$ & 115.2 & 109.9 & 111.9 \\
\hline $\operatorname{NFE}(\mathrm{g} / \mathrm{kg})^{3}$ & 460.5 & 461.7 & 461.7 \\
\hline Gross energy (kcal/kg) & 4347.27 & 4347.27 & 4347.27 \\
\hline \multicolumn{4}{|c|}{ 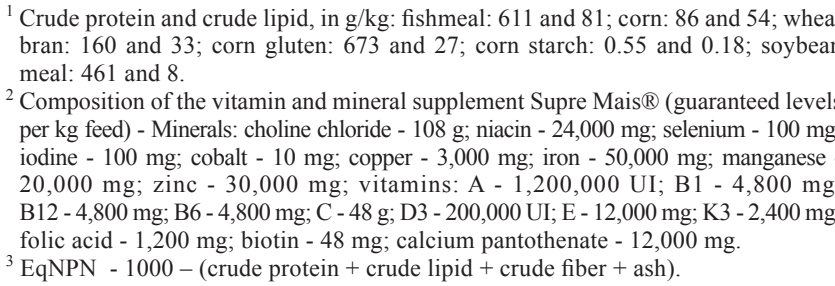 } \\
\hline
\end{tabular}

R. Bras. Zootec., v.41, n.9, p.1967-1974, 2012 
Table 2 - Fatty acid composition (mg/g) of the oils and experimental diets

\begin{tabular}{|c|c|c|c|c|c|c|}
\hline \multirow{2}{*}{ Fatty acids } & \multicolumn{3}{|c|}{ Oils } & \multicolumn{3}{|c|}{ Diets } \\
\hline & Soybean & Tilapia & Salmon & Soybean & Tilapia & Salmon \\
\hline C14:0 & 0.00 & 22.90 & 29.15 & 0.40 & 1.55 & 2.15 \\
\hline C16:0 & 93.65 & 192.65 & 125.25 & 14.30 & 18.30 & 14.90 \\
\hline C16:1 & 0.00 & 44.90 & 38.20 & 0.75 & 3.00 & 2.80 \\
\hline C17:0 & 1.00 & 1.90 & 2.90 & 0.25 & 0.20 & 0.30 \\
\hline C17:1 & 0.00 & 1.90 & 3.80 & 0.00 & 0.05 & 0.20 \\
\hline C18:1n-9 & 234.20 & 386.70 & 215.55 & 26.20 & 32.90 & 24.25 \\
\hline C18:2n-6 & 529.85 & 139.60 & 110.40 & 36.00 & 25.45 & 23.75 \\
\hline C18:3n-3 & 51.65 & 7.60 & 20.05 & 2.05 & 1.20 & 2.00 \\
\hline C20:0 & 3.80 & 1.90 & 1.90 & 0.55 & 0.45 & 0.40 \\
\hline C20:1n-11 & 3.35 & 18.65 & 31.50 & 0.40 & 1.10 & 1.90 \\
\hline $\mathrm{C} 22: 0$ & 5.70 & 1.00 & 1.00 & 0.80 & 0.25 & 0.25 \\
\hline C20:2n-6 & 0.00 & 9.60 & 19.10 & 0.40 & 0.50 & 1.00 \\
\hline C22:6n-3 & 0.00 & 4.80 & 117.60 & 0.20 & 0.50 & 5.65 \\
\hline$\sum$ sat $^{1}$ & 136.75 & 277.70 & 202.70 & 21.25 & 25.70 & 22.20 \\
\hline$\sum \mathrm{mono}^{2}$ & 237.55 & 454.10 & 297.80 & 27.70 & 36.70 & 29.40 \\
\hline$\sum$ poly $^{3}$ & 579.80 & 180.70 & 401.50 & 38.20 & 28.40 & 39.10 \\
\hline$\sum n-3$ & 51.65 & 16.50 & 250.95 & 2.30 & 1.95 & 13.45 \\
\hline$\sum \mathrm{n}-6$ & 528.20 & 164.40 & 149.60 & 35.90 & 26.45 & 25.70 \\
\hline$n-3 / n-6$ & 0.10 & 0.10 & 1.68 & 0.06 & 0.07 & 0.52 \\
\hline
\end{tabular}

${ }^{1}$ Sum of saturated fatty acid.

${ }^{2}$ Sum of monounsaturated fatty acid.

${ }^{3}$ Sum of polyunsaturated fatty acid.

chromatograph type GC-14B, Shimadzu was used, along with a fused silica capillary column, type OMEGAWAX250 $(30 \mathrm{~m} \times 0.25 \mathrm{~mm} \times 0.25$ a) $\mathrm{n} 0$ cat. 24136-SUPELCO, with the following analytical conditions and programming: $100^{\circ} \mathrm{C}$ for 2 minutes; heating $4{ }^{\circ} \mathrm{C} / \mathrm{min}$ up to $220{ }^{\circ} \mathrm{C}$ maintaining this temperature for 25 minutes; injector temperature of $250{ }^{\circ} \mathrm{C}$; temperature of the detector $280{ }^{\circ} \mathrm{C}$; gas carrier velocity (H2) of $1 \mathrm{ml} / \mathrm{min}$; SPLIT 1/100; injection volume of $1 \mu \mathrm{L}$; FID (Flame Ionization Detector).

Data were subjected to a variance analysis (ANOVA) at $5 \%$ probability, using the GLM procedure of software SAS (Statistical Analysis System, version 9.2). When interaction between factors (sex and diet) occurred, breaking down was performed and the Tukey test $(\mathrm{P}<0.05)$ was applied to evaluate comparisons of means; statistical differences were presented as interaction means. When the interaction between factors did not result in statistical significance, the differences were presented in the marginal means of each factor (sex and diet).

\section{Results and Discussion}

The different lipid sources used in this study (soybean oil, Nile tilapia residue oil and salmon residue oil) did not present any interaction in growth between the sexes (data not shown), which corroborates previous studies using different lipid sources at equivalent levels in the diet of fish (Caballero et al., 2002; Izquierdo et al., 2003; López et al., 2009; Martino et al., 2002; Turchini et al., 2003; Rosenlund et al., 2001).

The moisture and ash values taken from the carcasses of both male and females resulted in no difference, and interaction was observed between the mean values of crude protein and crude lipids (Table 3). Females had higher protein content in the muscle tissue compared with males, regardless of the diet consumed. The male lambari fed the diet containing soybean oil had higher levels of crude protein, followed by those on a diet with salmon oil and then finally tilapia oil. Both female and males fed soybean oil had a higher content of ether extract in their muscles than those fed the diet with fish oil (Table 3). No damage (necrosis or cell degeneration) was observed in the intestinal epithelium of Spaurus aurata that had been fed by replacing 60 to $80 \%$ of the fish oil content with vegetable oil (linseed, soybean, canola), but higher lipid deposition was verified in the enterocytes for fish fed vegetable oils (Caballero et al., 2003). On the other hand, the replacement of $60 \%$ of fish oil by soybean oil resulted in higher lipid deposition in the hepatocytes of rainbow trout (Caballero et al., 2002). 
Table 3 - Proximate composition $(\mathrm{g} / \mathrm{kg})$ of body proximate composition of male and female lambari

\begin{tabular}{|c|c|c|c|c|c|c|c|c|c|}
\hline \multirow{2}{*}{ Analysis } & \multirow{2}{*}{ Sex } & \multicolumn{3}{|c|}{ Lipid source of the diet } & \multirow{2}{*}{ Mean } & \multicolumn{3}{|c|}{$P$ value } & \multirow{2}{*}{$\mathrm{CV}(\%)$} \\
\hline & & Soybean oil & Tilapia residue oil & Salmon residue oil & & Diet & Sex & Diet*Sex & \\
\hline Moisture & Female & $697.3 \pm 2.70$ & $708.4 \pm 2.70$ & $707.4 \pm 2.70$ & $704.37 \pm 1.56 \mathrm{~A}$ & 0.323 & 0.057 & 0.461 & 5.24 \\
\hline Mean & Male & $\begin{array}{c}725.0 \pm 2.70 \\
711.15 \pm 1.91 \mathrm{a}\end{array}$ & $\begin{array}{c}749.2 \pm 2.70 \\
728.80 \pm 1.91 \mathrm{a}\end{array}$ & $\begin{array}{c}733.7 \pm 2.70 \\
720.55 \pm 1.91 \mathrm{a}\end{array}$ & $735.97 \pm 1.56 \mathrm{~A}$ & & & & \\
\hline $\begin{array}{l}\text { Crude protein } \\
\text { Mean }\end{array}$ & $\begin{array}{c}\text { Female } \\
\text { Male }\end{array}$ & $\begin{array}{c}187.3 \pm 0.13 \mathrm{Aa} \\
172.9 \pm 0.13 \mathrm{Ba} \\
180.10 \pm 0.09\end{array}$ & $\begin{array}{c}188.5 \pm 0.13 \mathrm{Aa} \\
155.0 \pm 0.13 \mathrm{Ac} \\
171.75 \pm 0.09\end{array}$ & $\begin{array}{c}185.8 \pm 0.13 \mathrm{Aa} \\
166.6 \pm 0.13 \mathrm{Ab} \\
176.2 \pm 0.09\end{array}$ & $\begin{array}{l}187.19 \pm 0.08 \\
164.82 \pm 0.08\end{array}$ & $<0.001$ & $<0.001$ & $<0.001$ & 1.31 \\
\hline Ash & $\begin{array}{c}\text { Female } \\
\text { Male }\end{array}$ & $\begin{array}{l}42.1 \pm 0.10 \\
46.1 \pm 1.10\end{array}$ & $\begin{array}{l}45.2 \pm 0.10 \\
40.5 \pm 0.10\end{array}$ & $\begin{array}{l}38.6 \pm 0.10 \\
42.9 \pm 0.10\end{array}$ & $\begin{array}{l}42.53 \pm 0.06 \mathrm{~A} \\
43.17 \pm 0.06 \mathrm{~A}\end{array}$ & 0.172 & 0.309 & 0.060 & 4.22 \\
\hline Mean & & $44.10 \pm 0.07 \mathrm{a}$ & $42.85 \pm 0.07 \mathrm{a}$ & $40.75 \pm 0.07 \mathrm{a}$ & & & & & \\
\hline Ether extract & $\begin{array}{c}\text { Female } \\
\text { Male }\end{array}$ & $\begin{array}{l}75.2 \pm 0.22 \mathrm{Aa} \\
63.6 \pm 0.22 \mathrm{Ba}\end{array}$ & $\begin{array}{l}50.3 \pm 0.22 \mathrm{Ab} \\
51.8 \pm 0.22 \mathrm{Ab}\end{array}$ & $\begin{array}{l}49.8 \pm 0.22 \mathrm{Ab} \\
46.8 \pm 0.22 \mathrm{Ab}\end{array}$ & $\begin{array}{l}58.42 \pm 0.13 \\
54.08 \pm 0.13\end{array}$ & $<0.001$ & 0.033 & 0.035 & 6.80 \\
\hline Mean & & $69.40 \pm 0.16$ & $51.05 \pm 0.16$ & $48.30 \pm 0.16$ & & & & & \\
\hline
\end{tabular}

Means followed by different lowercase and capital letters in rows and columns, respectively, differ by the Tukey test ( $\mathrm{P}=5 \%)$.

$\mathrm{CV}$ - coefficient of variation.

In a study that described the fatty acid composition of commercially important fish from Brazil, the palmitic acid was the predominant fatty acid, followed by C16:1, C18:1 and C14:0 in the flesh of lambari (Gutierrez \& Silva, 1993). In the present study, the fatty acids found in greatest amounts, both in the diets (Table 3 ) as well as in the lambari muscle tissue (Table 4), were: oleic (C18:1n-9); linoleic (C18:2n-6); palmitic (C16:0) and stearic (C18:0), which is probably related to the inclusion of vegetable ingredients in the experimental diets. The palmitic acid was the most abundant, followed by stearic, oleic acid, EPA and DHA in the liver and muscle tissue fatty acid profile from male and female Salmo trutta macrostigma (Akpinar et al., 2009). Despite being a freshwater fish, the trout presented high levels of EPA and DHA, which may be related to the lower temperature necessary for the survival of this species as well as the fact that they were captured directly from the river, i.e., from their natural food environment or still having the ability of elongation and desaturation of precursory fatty acids.

Studies conducted by Izquierdo et al. (2003), MartínezLlorens et al. (2007), Martino et al. (2002) and Vargas et al. (2008) verified that the fatty acid profile of the diet reflects on the composition of fatty acids in fish tissue. Linoleic acid (C18: 2n-6) was found at higher levels among the polyunsaturated fatty acids in the oils and the experimental diets, except for salmon oil, which showed to have a higher concentration of DHA. Soybean oil is an ingredient rich in linoleic acid $(529.85 \mathrm{mg} / \mathrm{g})$, which was reflected in the $\operatorname{diet}(36.00 \mathrm{mg} / \mathrm{g})$ as well as in the muscle tissue of male $(10.95 \mathrm{mg} / \mathrm{g})$ and female fish $(14.70 \mathrm{mg} / \mathrm{g})$ (Table 3). They had been fed soybean oil, which had a greater amount of this fatty acid compared with the two other experimental groups (tilapia: $25.45,6.50$ and $8.85 \mathrm{mg} / \mathrm{g}$; salmon: 23.75 , 8.70 and $9.90 \mathrm{mg} / \mathrm{g}$, respectively).

The muscle tissue from animals fed the salmon-oil diet showed higher values of saturated fatty acids (males: 15.30 and females: $20.10 \mathrm{mg} / \mathrm{g}$ ) and monounsaturated fatty acids (males: 21.45 and females: $23.10 \mathrm{mg} / \mathrm{g}$ ), and the mean values of polyunsaturated fatty acids were higher in muscle tissue from fish on soybean oil (males: 14.75 and females: $18.60 \mathrm{mg} / \mathrm{g}$ ), followed by salmon oil (males: 13.30 and females: $14.65 \mathrm{mg} / \mathrm{g}$ ) and TI (males: 9.25 and females: $12.45 \mathrm{mg} / \mathrm{g}$ ) regardless of the sex (Table 5).

Female muscle tissue had higher levels than males in most of the fatty acids which were different for the sex factor $(\mathrm{P}<0.001$ or $\mathrm{P}<0.01)$. The greater accumulation of these fatty acids in females is probably related to their greater need to retain energy. This is because during the period of ovarian maturation, females require a large availability of macro and micronutrients for transfer to the oocytes (Cejas et al., 2004). As lipid mobilization depends on the species of fish, this may be obtained from the fat reserves of one or more tissues, particularly muscle and liver tissues (Adams, 1999).

The levels of essential linoleic fatty acid (C18:3n-3) were found to be higher in the muscle tissue from fish fed soybean and salmon oils, for both male and female groups. The arachidonic fatty acid (ARA - C20: 4n-6) is the major eicosanoid precursor in fish cells as the prostaglandins, thromboxans and leukotrienes (Bell et al., 1994) and it controls many physiological functions, including reproduction (Sargent et al., 1999). The prostaglandins stimulate ovarian and testicular steroidogenesis and the ovulation control (Kellner \& Van Der Kraak, 1993). The arachidonic fatty acid was present at higher concentrations 
Table 4 - Fatty acid composition ( $\mathrm{mg} / \mathrm{g})$ of the muscle tissue from male and female lambari

\begin{tabular}{|c|c|c|c|c|c|c|c|c|c|}
\hline \multirow{2}{*}{ Fatty acids } & \multirow{2}{*}{ Sex } & \multicolumn{3}{|c|}{ Lipid source of the diet } & \multirow{2}{*}{ Mean } & \multicolumn{3}{|c|}{$P$ value } & \multirow{2}{*}{$\mathrm{CV}(\%)$} \\
\hline & & Soybean oil & Tilapia residue oil & Salmon residue oil & & Diet & Sex & Diet*Sex & \\
\hline C14:0 & $\begin{array}{l}\text { Female } \\
\text { Male }\end{array}$ & $\begin{array}{l}0.40 \pm 0.02 \mathrm{Ac} \\
0.30 \pm 0.02 \mathrm{Bb}\end{array}$ & $\begin{array}{c}0.70 \pm 0.02 \mathrm{Ab} \\
0.45 \pm 0.02 \mathrm{Bab}\end{array}$ & $\begin{array}{l}1.05 \pm 0.02 \mathrm{Aa} \\
0.60 \pm 0.02 \mathrm{Ba}\end{array}$ & $\begin{array}{l}0.72 \pm 0.01 \\
0.45 \pm 0.01\end{array}$ & $<0.001$ & $<0.001$ & 0.003 & 7.00 \\
\hline Mean & & $0.35 \pm 0.01$ & $0.57 \pm 0.01$ & $0.82 \pm 0.01$ & & & & & \\
\hline $\begin{array}{l}\text { C15:0 } \\
\text { Mean }\end{array}$ & $\begin{array}{l}\text { Female } \\
\text { Male }\end{array}$ & $\begin{array}{c}0.10 \pm 0.00 \mathrm{Ab} \\
0.10 \pm 0.00 \mathrm{Ab} \\
0.10 \pm 0.00\end{array}$ & $\begin{array}{c}0.10 \pm 0.00 \mathrm{Ab} \\
0.10 \pm 0.00 \mathrm{Ab} \\
0.10 \pm 0.00\end{array}$ & $\begin{array}{c}0.20 \pm 0.00 \mathrm{Aa} \\
0.10 \pm 0.00 \mathrm{Bb} \\
0.15 \pm 0.00\end{array}$ & $\begin{array}{l}0.13 \pm 0.00 \\
0.10 \pm 0.00\end{array}$ & $<0.001$ & $<0.001$ & $<0.001$ & 0.00 \\
\hline $\begin{array}{l}\text { C16:1 } \\
\text { Mean }\end{array}$ & $\begin{array}{l}\text { Female } \\
\text { Male }\end{array}$ & $\begin{array}{c}1.10 \pm 0.02 \mathrm{Ac} \\
0.80 \pm 0.02 \mathrm{Bc} \\
0.95 \pm 0.01\end{array}$ & $\begin{array}{c}1.55 \pm 0.02 \mathrm{Ab} \\
1.15 \pm 0.02 \mathrm{Bb} \\
1.35 \pm 0.01\end{array}$ & $\begin{array}{c}2.10 \pm 0.02 \mathrm{Aa} \\
1.50 \pm 0.02 \mathrm{Ba} \\
1.80 \pm 0.01\end{array}$ & $\begin{array}{l}1.58 \pm 0.01 \\
1.15 \pm 0.01\end{array}$ & $<0.001$ & $<0.001$ & 0.005 & 2.99 \\
\hline $\begin{array}{l}\text { C18:2n-6 } \\
\text { Mean }\end{array}$ & $\begin{array}{l}\text { Female } \\
\text { Male }\end{array}$ & $\begin{array}{c}14.70 \pm 0.10 \mathrm{Aa} \\
10.95 \pm 0.10 \mathrm{Ba} \\
12.82 \pm 0.07\end{array}$ & $\begin{array}{c}8.85 \pm 0.10 \mathrm{Ab} \\
6.50 \pm 0.10 \mathrm{Bc} \\
7.67 \pm 0.07\end{array}$ & $\begin{array}{c}9.90 \pm 0.10 \mathrm{Ab} \\
8.70 \pm 0.10 \mathrm{Bb} \\
9.30 \pm 0.07\end{array}$ & $\begin{array}{c}11.15 \pm 0.06 \\
8.72 \pm 0.06\end{array}$ & $<0.001$ & $<0.001$ & 0.001 & 2.29 \\
\hline $\begin{array}{l}\text { C18:3n-6 } \\
\text { Mean }\end{array}$ & $\begin{array}{l}\text { Female } \\
\text { Male }\end{array}$ & $\begin{array}{c}0.30 \pm 0.00 \mathrm{Aa} \\
0.20 \pm 0.00 \mathrm{Ba} \\
0.25 \pm 0.00\end{array}$ & $\begin{array}{c}0.30 \pm 0.00 \mathrm{Aa} \\
0.20 \pm 0.00 \mathrm{Ba} \\
0.25 \pm 0.00\end{array}$ & $\begin{array}{c}0.20 \pm 0.00 \mathrm{Ab} \\
0.20 \pm 0.00 \mathrm{Aa} \\
0.20 \pm 0.00\end{array}$ & $\begin{array}{l}0.27 \pm 0.00 \\
0.20 \pm 0.00\end{array}$ & $<0.001$ & $<0.001$ & $<0.001$ & 0.00 \\
\hline $\begin{array}{l}\text { C18:3n-3 } \\
\text { Mean }\end{array}$ & $\begin{array}{l}\text { Female } \\
\text { Male }\end{array}$ & $\begin{array}{c}0.60 \pm 0.01 \mathrm{Aa} \\
0.50 \pm 0.01 \mathrm{Ba} \\
0.55 \pm 0.01\end{array}$ & $\begin{array}{c}0.30 \pm 0.01 \mathrm{Ab} \\
0.30 \pm 0.01 \mathrm{Ab} \\
0.30 \pm 0.01\end{array}$ & $\begin{array}{c}0.60 \pm 0.01 \mathrm{Aa} \\
0.45 \pm 0.01 \mathrm{Ba} \\
0.52 \pm 0.01\end{array}$ & $\begin{array}{l}0.50 \pm 0.00 \\
0.42 \pm 0.00\end{array}$ & $<0.001$ & 0.002 & 0.027 & 6.30 \\
\hline C20:5n-3 & $\begin{array}{l}\text { Female } \\
\text { Male }\end{array}$ & $\begin{array}{c}0.10 \pm 0.00 \mathrm{Ab} \\
0.10 \pm 0.00 \mathrm{Ab} \\
0.10 \pm 0.00\end{array}$ & $\begin{array}{c}0.10 \pm 0.00 \mathrm{Ab} \\
0.10 \pm 0.00 \mathrm{Ab} \\
0.10 \pm 0.00\end{array}$ & $\begin{array}{c}0.80 \pm 0.00 \mathrm{Aa} \\
0.50 \pm 0.00 \mathrm{Ba} \\
0.10 \pm 0.00\end{array}$ & $\begin{array}{l}0.33 \pm 0.00 \\
0.23 \pm 0.00\end{array}$ & $<0.001$ & $<0.001$ & $<0.001$ & 0.00 \\
\hline$C 22: 6 n-3$ & $\begin{array}{l}\text { Female } \\
\text { Male }\end{array}$ & $\begin{array}{c}1.00 \pm 0.02 \mathrm{Bb} \\
1.35 \pm 0.02 \mathrm{Ab} \\
1.17 \pm 0.01\end{array}$ & $\begin{array}{c}1.15 \pm 0.02 \mathrm{Ab} \\
0.80 \pm 0.02 \mathrm{Bc} \\
0.97 \pm 0.01\end{array}$ & $\begin{array}{c}2.15 \pm 0.02 \mathrm{Aa} \\
2.25 \pm 0.02 \mathrm{Aa} \\
2.20 \pm 0.01\end{array}$ & $\begin{array}{l}1.43 \pm 0.01 \\
1.47 \pm 0.01\end{array}$ & $<0.001$ & 0.356 & $<0.001$ & 3.98 \\
\hline
\end{tabular}

Means followed by different lowercase and capital letters in rows and columns, respectively, differ by the Tukey test ( $\mathrm{P}=5 \%)$.

$\mathrm{CV}$ - coefficient of variation.

in the muscle tissue of both males and females fed soybean oil and tilapia residue oil, and this can be related to higher levels of C18:2n-6 in oils and diets of these treatments, because linoleic acid is a precursor of the arachidonic acid synthesis.

However, higher amounts of EPA and DHA were observed in the muscle tissue of females (EPA: 0.80 and DHA: $2.15 \mathrm{mg} / \mathrm{g}$ ) and males (EPA: 0.50 and DHA: $2.25 \mathrm{mg} / \mathrm{g}$ ) that had been fed salmon oil.
Lambaris of both sexes which received the soybean oil diet had higher levels of $n-6$ fatty acids, especially C18:2n-6, which is to be found in large amounts in vegetable oils. On the other hand, lambari of both sex fed the diet with salmon oil demonstrated higher levels of n-3 fatty acids, especially EPA and DHA. Both of them are typically found in seawater fish oil. Seawater fish require a supply of EPA and DHA (NRC, 1993) because they have limited capacity (Sargent et al., 2002) or inability (Tocher, 2010) to carry 
out the biosynthesis of EPA and DHA from their shortchain precursors, due to the lack of a $\Delta 5$ desaturase gene. Thus, the oil extracted from salmon residues is a source of long-chain omega 3 fatty acid (Wu \& Bechtel, 2008).

Unlike seawater fish, almost all freshwater fish have the ability to convert linoleic acid (C18: $2 n-6)$ into arachidonic acid (C20: 4n-6) and the linolenic acid (C18: 3n-3) into EPA (20 : 5n-3) and finally into DHA (C22: 6n-3), through a process involving a series of desaturation and elongation enzymes (Sargent et al., 2002; Turchini et al., 2006). It is suggested that lambari have the capacity of elongation and desaturation due to a greater presence of DHA and a decrease in linolenic acid levels found in the muscle tissue than in diets with soybean oil and tilapia residue oil, for both sexes. This fact was also evident in other Brazilian species of freshwater fish, such as pintado, Pseudoplatystoma coruscans (Martino et al., 2002; Tanamati et al., 2009); jundiá, Rhamdia quelen (Vargas et al., 2008); pacu, Piaractus mesopotamicus (Tanamati et al., 2009); and matrinxã, Brycon cephalus (Almeida \& Franco, 2007).

However, the fish groups of both sexes demonstrated low values of these long-chain fatty acids, with maximum $0.8 \mathrm{mg} / \mathrm{g}$ for EPA and $2.25 \mathrm{mg} / \mathrm{g}$ for DHA, which can be related to the diet composition. Studies have reported (Tocher et al., 2002; Francis et al., 2009) that the supply of feed with higher amounts of EPA and DHA decreases the desaturases activities, resulting in no or low generation of synthesis of EPA and DHA. Thus, the levels of EPA and DHA in the muscle of the fish fed salmon oil are related, largely, to the deposition from the diet. And in fish fed diets prepared with soybean oil and tilapia residue oil, it would not have enough precursor for EPA and DHA production. Another hypothesis can be that the highly unsaturated fatty acids are transferred to other tissue(s) of the fish, and probably, this it is not related to the muscle.

Females and males fed diets containing fish residue oil (tilapia residue oil and salmon oil) had a n3/n-6 ratio higher than the minimum values $(>0.25)$ recommended by the World Health Organization for the prevention of coronary heart disease. However, fish of both sexes fed soybean oil demonstrated lower values. Due to the nutritional importance of polyunsaturated fatty acids for humans, it is recommended to feed the fish with fish-oil-based diets, at least during the finishing period (Fountoulaki et al., 2009) in order to ensure appropriate levels of n-3 fatty acids in their organisms. In addition, the use of fish residue as an alternative ingredient to the nutrition of aquatic organisms adds value to the products generated by aquaculture and contributes to the sustainability of this activity.

Table 5 - Total fatty acid composition, sum of fatty acid class $(\mathrm{mg} / \mathrm{g})$ and n-3/n-6 ratio of muscle tissue from male and female lambari

\begin{tabular}{|c|c|c|c|c|c|c|c|c|c|}
\hline \multirow{2}{*}{ Fatty acid } & \multirow{2}{*}{ Sex } & \multicolumn{3}{|c|}{ Treatments } & \multirow{2}{*}{ Mean } & \multicolumn{3}{|c|}{$P$ value } & \multirow{2}{*}{ CV $(\%)$} \\
\hline & & Soybean oil & Tilapia residue oil & Salmon residue oil & & Diet & Sex & Diet*Sex & \\
\hline \multirow[t]{2}{*}{ Total } & \multirow{3}{*}{$\begin{array}{l}\text { Female } \\
\text { Male }\end{array}$} & $56.30 \pm 0.41$ & $52.30 \pm 0.41$ & $59.80 \pm 0.41$ & \multirow{3}{*}{$\begin{array}{l}56.13 \pm 0.24 \mathrm{~A} \\
47.45 \pm 0.24 \mathrm{~B}\end{array}$} & \multirow[t]{3}{*}{$<0.001$} & \multirow[t]{3}{*}{$<0.001$} & \multirow[t]{3}{*}{0.142} & \multirow[t]{3}{*}{1.93} \\
\hline & & $48.65 \pm 0.41$ & $41.70 \pm 0.41$ & $52.00 \pm 0.41$ & & & & & \\
\hline Mean & & $52.47 \pm 0.29 \mathrm{ab}$ & $47.00 \pm 0.29 \mathrm{~b}$ & $55.90 \pm 0.29 \mathrm{a}$ & & & & & \\
\hline \multirow[t]{2}{*}{$\sum \mathrm{Sat}^{1}$} & \multirow{3}{*}{$\begin{array}{l}\text { Female } \\
\text { Male }\end{array}$} & $16.90 \pm 0.13$ & $17.70 \pm 0.13$ & $20.10 \pm 0.13$ & \multirow{3}{*}{$\begin{array}{l}18.23 \pm 0.08 \mathrm{~A} \\
13.87 \pm 0.08 \mathrm{~B}\end{array}$} & \multirow[t]{3}{*}{$<0.001$} & \multirow[t]{3}{*}{$<0.001$} & \multirow[t]{3}{*}{0.172} & \multirow[t]{3}{*}{2.07} \\
\hline & & $13.10 \pm 0.13$ & $13.20 \pm 0.13$ & $15.30 \pm 0.13$ & & & & & \\
\hline Mean & & $15.00 \pm 0.09 \mathrm{~b}$ & $15.45 \pm 0.09 \mathrm{~b}$ & $17.70 \pm 0.09 \mathrm{a}$ & & & & & \\
\hline \multirow{2}{*}{$\sum$ Mono $^{2}$} & \multirow{3}{*}{$\begin{array}{l}\text { Female } \\
\text { Male }\end{array}$} & $18.65 \pm 0.15 \mathrm{Ab}$ & $19.75 \pm 0.15 \mathrm{Ab}$ & $23.10 \pm 0.15 \mathrm{Aa}$ & \multirow{3}{*}{$\begin{array}{l}20.50 \pm 0.09 \\
19.48 \pm 0.09\end{array}$} & \multirow[t]{3}{*}{$<0.001$} & \multirow[t]{3}{*}{0.003} & \multirow[t]{3}{*}{0.006} & \multirow[t]{3}{*}{1.87} \\
\hline & & $19.20 \pm 0.15 \mathrm{Ab}$ & $17.80 \pm 0.15 \mathrm{Bb}$ & $21.45 \pm 0.15 \mathrm{Ba}$ & & & & & \\
\hline Mean & & $18.92 \pm 0.11$ & $18.77 \pm 0.11$ & $22.27 \pm 0.11$ & & & & & \\
\hline \multirow[t]{2}{*}{$\sum$ Poly $^{3}$} & \multirow{3}{*}{$\begin{array}{l}\text { Female } \\
\text { Male }\end{array}$} & $18.60 \pm 0.14 \mathrm{Aa}$ & $12.45 \pm 0.14 \mathrm{Ac}$ & $14.65 \pm 0.14 \mathrm{Ab}$ & $15.23 \pm 0.08$ & \multirow[t]{3}{*}{$<0.001$} & \multirow[t]{3}{*}{$<0.001$} & \multirow[t]{3}{*}{0.006} & \multirow[t]{3}{*}{2.54} \\
\hline & & $14.75 \pm 0.14 \mathrm{Ba}$ & $9.25 \pm 0.14 \mathrm{Bc}$ & $13.30 \pm 0.14 \mathrm{Bb}$ & $12.43 \pm 0.08$ & & & & \\
\hline Mean & & $16.67 \pm 0.10$ & $10.85 \pm 0.10$ & $13.97 \pm 0.10$ & & & & & \\
\hline$\sum n-3$ & Female & $2.70 \pm 0.04 \mathrm{Ab}$ & $2.40 \pm 0.04 \mathrm{Ab}$ & $3.95 \pm 0.04 \mathrm{Aa}$ & $3.17 \pm 0.02$ & $<0.001$ & 0.006 & 0.009 & 3.60 \\
\hline & Male & $2.80 \pm 0.04 \mathrm{Ab}$ & $1.80 \pm 0.04 \mathrm{Bc}$ & $3.70 \pm 0.04 \mathrm{Ba}$ & $2.77 \pm 0.02$ & & & & \\
\hline Mean & & $2.75 \pm 0.03$ & $2.10 \pm 0.03$ & $3.82 \pm 0.03$ & & & & & \\
\hline$\sum \mathrm{n}-6$ & Female & $15.60 \pm 0.10 \mathrm{Aa}$ & $9.70 \pm 0.10 \mathrm{Ab}$ & $10.40 \pm 0.10 \mathrm{Ab}$ & $11.90 \pm 0.06$ & $<0.001$ & $<0.001$ & $<0.001$ & 2.25 \\
\hline & Male & $11.65 \pm 0.10 \mathrm{Ba}$ & $7.20 \pm 0.10 \mathrm{Bc}$ & $9.30 \pm 0.10 \mathrm{Bb}$ & $9.38 \pm 0.06$ & & & & \\
\hline Mean & & $13.62 \pm 0.07$ & $8.45 \pm 0.07$ & $9.85 \pm 0.07$ & & & & & \\
\hline$n-3 / n-6$ & Female & $0.17 \pm 0.01 \mathrm{Bc}$ & $0.25 \pm 0.01 \mathrm{Ab}$ & $0.38 \pm 0.01 \mathrm{Aa}$ & $0.27 \pm 0.00$ & $<0.001$ & $<0.001$ & $<0.001$ & 2.07 \\
\hline & Male & $0.24 \pm 0.01 \mathrm{Ab}$ & $0.25 \pm 0.01 \mathrm{Ab}$ & $0.40 \pm 0.01 \mathrm{Aa}$ & $0.30 \pm 0.00$ & & & & \\
\hline Mean & & $0.20 \pm 0.01$ & $0.25 \pm 0.01$ & $0.39 \pm 0.01$ & & & & & \\
\hline
\end{tabular}

Means followed by different lowercase and capital letters in rows and columns, respectively, differ by the Tukey test ( $\mathrm{P}=5 \%)$

$\mathrm{CV}$ - coefficient of variation.

${ }^{1}$ Sum of saturated fatty acid.

${ }^{2}$ Sum of monounsaturated fatty acid.

${ }^{3}$ Sum of polyunsaturated fatty acid. 


\section{Conclusions}

The fatty acid profile of the muscle from male and female lambari showed similar composition across the experimental diets, with a highlight to the salmon oil, which promoted significant deposition of n-3 highly unsaturated fatty acid. The oil extracted from salmon and tilapia residue can be a substitute for traditional fish oil, once it does not hinder the growth performance and provides levels of n-3 fatty acids above the minimum required for good nutritional health in humans.

\section{Acknowledgments}

The authors would like to thank Fundação de Amparo à Pesquisa do Estado de São Paulo - FAPESP for funding this research (2006/06615-3) and for granting the $\mathrm{PhD}$ fellowship (2007/53876-0) to L.U. Gonçalves; and Conselho Nacional de Desenvolvimento Científico e Tecnológico - CNPq for granting the fellowship of scientific initiation (109613/2007-4) to F. Ferroli and for the fellowship of research productivity (3078888/2006-1) to E.M.M.Viegas.

\section{References}

ABIMORAD, E.G.; CASTELLANI, D. Amino acid requirements of lambari-do-rabo-amarelo based on whole body and muscle composition. Boletim do Instituto de Pesca, v.37, p.31-38, 2011.

ADAMS, S.M. Ecological role of lipids in the health and success of fish populations. In: ARTS, M.T.; WAINMAN, B.C. (Eds.) Lipids in Freshwater Ecosystems. New York: USA, 1999. p.425-434.

AKPINAR, M.A.; GÖRGUN, S.; AKPINAR, A.E. A comparative analysis of the fatty acids profiles in the liver and muscle of male and female Salmo trutta macrostigma. Food Chemistry, v.112, p.6-8, 2009.

ALMEIDA, N.M.; FRANCO, M.R.B. Fatty acid composition of total lipids, neutral lipids and phospholipids in wild and farmed matrinxã (Brycon cephalus) in the Brazilian Amazon area. Journal of the Science of Food and Agriculture, v.87, p.2596-2603, 2007.

ASSOCIATION OF OFFICIAL ANALYTICAL CHEMISTIS AOAC. Official methods of analysis. 18.ed. Arlington: AOAC International, 2005. 1141p.

BAZAN, N.G. Cell survival matters: docosahexaenoic acid signaling, neuroprotection and photoreceptors. Trends in Neurosciences, v.29, p.264-271, 2006.

BELL, J.G.; TOCHER, D.R.; MACDONALD, F.M. et al. Effect of supplementation with $(20: 3 n-6),(20: 4 n-6)$ and $(20: 5 n-3)$ on the production of prostaglandin-e and prostaglandin-f on the 1-series, 2 -series and 3 -series in turbot (Scophthalmus maximus) brain astroglial cells in primary culture. Biochimica Biophysica Acta, v.1211, p.335- 342, 1994.

BLIGH, E.G.; DYER, W.J. A rapid method of total lipid extraction and purification. Canadian Journal of Biochemistry and Physiology, v.37, p.911-917, 1959.

BOSCOLO, W.R.; SIGNOR, A.A.; SIGNO, A. et al. Partial and total substitution of soy oil for tilapia oil in rations for larvae of Nile tilapia (Oreochromis niloticus). Semina: Ciências Agrárias, v.29, p.707-712, 2008.
CABALlERO, M.J.; OBACH, A.; ROSENLUND, G. et al. Impact of different dietary lipid sources on growth, lipid digestibility, tissue fatty acid composition and histology of rainbow trout, Oncorhynchus mykiss. Aquaculture, v.214, p.253-271, 2002.

CABALlERO, M.J.; IZQUIERDO, M.S.; KJORSVIK, E. et al. Morphological aspects of intestinal cells from gilthead seabream (Spaurus aurata) fed diets containing different lipid sources. Aquaculture, v.225, p.323-340, 2003.

CEJAS, J.S.; ALMANSA, E.; JÉREZ, S. et al. Lipid and fatty acid composition of muscle and liver from wild and captive mature female broodstocks of white seabream, Diplodus sargus. Comparative Biochemistry and Physiology Part B, v.138, p.91-102, 2004.

COTAN, J.L.V.; LANNA, E.A.T.; BOMFIM, M.A.D. et al. Dietary levels of digestible energy and crude protein for lambaris tambiú fingerlings. Revista Brasileira de Zootecnia, v.35, p.634-640, 2006.

FOOD AGRICULTURE ORGANIZATION - FAO. State of world aquaculture. Fisheries Technical Paper, 2010. 197p.

FOUNTOULAKI, E.; VASILAKI, A.; HURTADO, R. et al. Fish oil substitution by vegetable oils in commercial diets for gilthead sea bream (Sparus aurata L.); effects on growth performance, flesh quality and fillet fatty acid profile. Recovery of fatty acid profiles by a fish oil finishing diet under fluctuating water temperatures. Aquaculture, v.289, p.317-326, 2009.

FRANCIS. D.S.; PETERS. D.S; TURCHINI. G.M. Apparent in vivo $\Delta-6$ desaturase activity. Efficiency. and affinity are affected by total dietary C 18 PUFA in the freshwater fish murray cod. Journal of Agricultural and Food Chemistry, v.57, p.4381-4390, 2009.

GARUTTI, V.; BRITSKI, H.A. Descrição de uma espécie nova de Astyanax (Teleostei:Characidae) da bacia do alto rio Paraná e considerações sobre as demais espécies do gênero na bacia. Comunicações do Museu de Ciência e Tecnologia, v.13, p.65-88, 2000 .

GUTIERREZ, L.E.; SILVA, R.C.M. Fatty acid composition of commercially important fish from Brazil. Scientia Agricola, v.50, p.478-483, 1993.

HAYASHI, C.; MEURER, F.; BOSCOLO, W.R. et al. Feeding frequency for yellow tail lambari (Astyanax bimaculatus) fingerlings. Revista Brasileira de Zootecnia, v.33, p.21-26, 2004.

HARTMAN, L.; LAGO, R.C.A. Rapid preparation of fatty acid methyl esters from lipids. Laboratory Pratice, v.22, p.475-477, 1973.

IZQUIERDO, M.S.; OBACH, A.; ARANTZAMENDI, L. et al. Dietary lipid sources for seabream and seabass: growth performance, tissue composition and flesh quality. Aquaculture Nutrition, v.9, p.397-407, 2003.

KELLNER, R.G.; VAN DER KRAAK, G. Multifactorial regulation of prostaglandin Synthesis in preovulatory goldfish ovarian follicles. Biology of Reproduction, v.46, p.630-635, 1992.

LÓPEZ, L.M.; DURAZO, E.; VIANA, M.T. et al. Effect of dietary lipid levels on performance. body composition and fatty acid profile of juvenile white seabass, Atractoscion nobilis. Aquaculture, v.289, p.101-105, 2009.

MARTÍNEZ-LLORENS, S.; VIDAL, A.T.; MOÑINO, A.V. et al. Effects of dietary soybean oil concentration on growth, nutrient utilization and muscle fatty acid compostition of gilthead sea bream (Sparus aurata L.). Aquaculture Research, v.38, p.76-81, 2007.

MARTINO, R.C.; CYRINO, J.E.P.; PORTZ, L. et al. Performance and fatty acid composition of surubim (Pseudoplatystoma coruscans) fed diets with animal and plant lipids. Aquaculture, v.209, p.233-246, 2002.

MEURER, F.; HAYASHI, C.; BOSCOLO, W.R. et al. Feeding level for yellow tail Lambari (Astyanax bimaculatus) fingerlings. Revista Brasileira de Zootecnia, v.34, p.1835-1840, 2005.

MOZAFFARIAN, D.; BRYSON, C.L.; LEMAITRE, R.N. et al. Fish Intake and Risk of Incident Heart Failure. Journal of the American College of Cardiology, v.45, p.2015-2021, 2005. 
O'NEAL, C.C.; KOHLER, C.C. Effect of replacing menhaden oil with catfish oil on the fatty acid composition of juveniles channel catfish, Ictalurus punctatus. Journal of the World Aquaculture Society, v.39, p.62-71, 2008.

PORTO-FORESTI,F.;CASTILHO-ALMEIDA,R.B.;FORESTI,F.Biologia e criação do lambari-do-rabo-amarelo. In: BALDISSEROTTO, B; GOMES, L.C. (Eds.). Espécies nativas para piscicultura no Brasil. 1.ed. Santa Maria: RS, 2005. p.105-120.

ROSENLUND, G.; OBACH, A.; SANDBERG. M.G. et al. Effect of alternative lipid sources on long-term growth performance and quality of Atlantic salmon (Salmo salar L.). Aquaculture Research, v.32, p.323-328, 2001.

SARGENT, J.R.; BELL, J.G.; MCEVOY, L.A. et al. Recent developments in the essential fatty acid nutrition of fish. Aquaculture, v.177, p.191-199, 1999.

SARGENT, J.R.; TOCHER, D.R.; BELL, J.G. The lipids. In: HALVER, J.E.; HARDY, R.W. (Eds.) Fish nutrition. USA, 2002. p.181-257.

SIGNOR, A.A.; BOSCOLO, W.R.; BITTENCOURT, F. et al. Poultry by-product meal in lambaris fingerlings diet. Revista Brasileira de Zootecnia, v.38, p.2339-2344, 2008.

TACON, A.G.J; METIAN, M. Global overview on the use of fish meal and fish oil industrially compounded aquafeeds: trends and future prospects. Aquaculture, v.285, p.146-158, 2008.

TANAMATI, A.; STEVANATO, F.B.; VISENTAINER, J.E.L. et al. Fatty acid composition in wild and cultivated pacu and pintado fish. European Journal of Lipid Science and Technology, v.111, p.183-187, 2009

TOCHER. D.R.; FONSECA-MADRIGAL, J.; BELL. J.G. et al. Effects of diets containing linseed oil on fatty acid desaturation and oxidation in hepatocytes and intestinal enterocytes in Atlantic salmon (Salmo salar). Fish Physiology Biochemistry, v.26. p.157-170, 2002.

TOCHER, D.R. Fatty acid requirements in ontogeny of marine and freshwater fish. Aquaculture Research, v.41, p.717-732, 2010 .

TURCHINI, G.M.; GUNASEKERA, R.M.; DE SILVA, S.S. Effect of crude oil extracts from trout offal as a replacement for fish oil in the diets of the Australian native fish Murray cod (Maccullochella peelii peelii). Aquaculture Research, v.34, p.697-708, 2003.

TURCHINI, G.M.; FRANCIS, D.S.; DE SILVA, S.S. Fatty acid metabolism in the freshwater fish Murray cod (Maccullochella peelii peelii) deduced by the whole-body fatty acid balanced method. Comparative Biochemistry and Physiology Part B, v.144, p.110-118, 2006.

TURCHINI, G.M.; TORSTENSEN, B.E.; WING-KEONG, N.G. Fish oil replacement in finfish nutrition. Reviews in Aquaculture, v.1, p.10-57, 2009.

VARGAS, R.J.; SOUZA, S.M.G.; KESSLER, A.M. et al. Replacement of fish oil with vegetable oils in diets for jundiá (Rhamdia quelen Quoy and Gaimard 1824): effects on performance and whole body fatty acid composition. Aquaculture Research, v.39, p.657-665, 2008 .

VILELA, C.; HAYASHI, C. Development of Astyanax bimaculatus (Linnaeus, 1758) juveniles at different stocking densities in net ponds. Acta Scientiarum, v.23, p.491-496, 2001.

WU, T.D.; BECHTEL, P.J. Salmon by-product storage and oil extraction. Food Chemistry, v.111, p.868-871, 2008. 